\title{
Tinjauan Etika Kristen Terhadap Korban Napza
}

Oleh:

R. Bimo Ario Tedjo, S.E, S.Th

Ferdinan Pasaribu, S.Th 


\section{DAFTAR ISI}

COVER

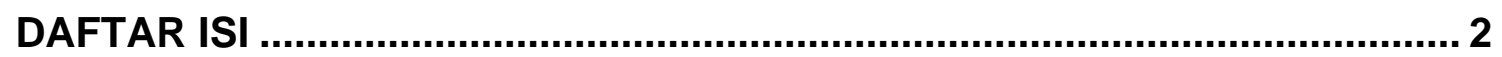

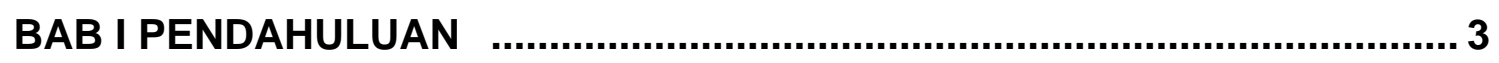

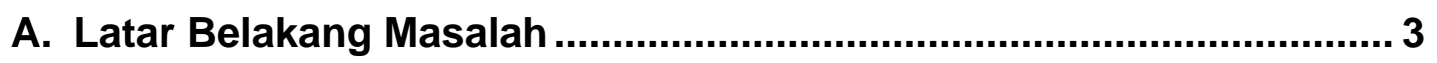

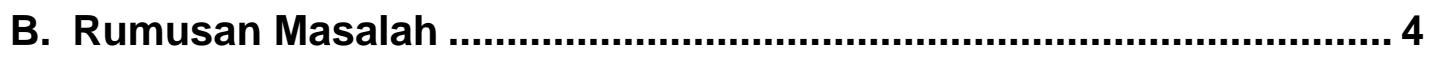

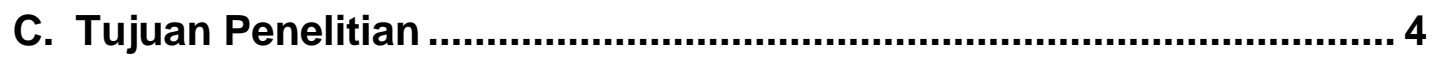

BAB II NAPZA

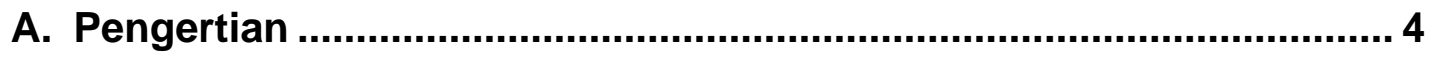

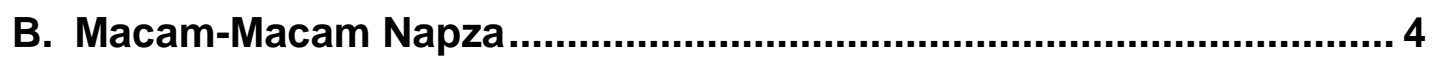

C. Contoh Jenis-Jenis Napza ……................................................ 5

BAB III METODE PENELITIAN DAN HASIL PENELITIAN.............................. 5

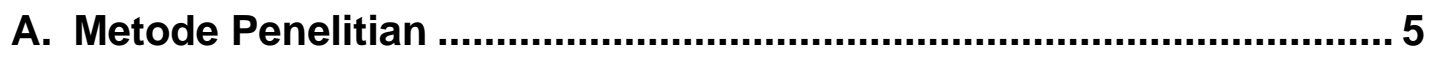

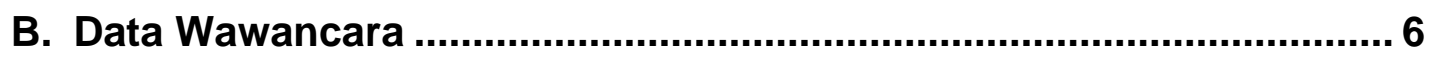

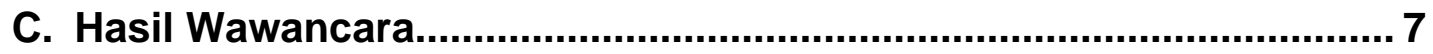

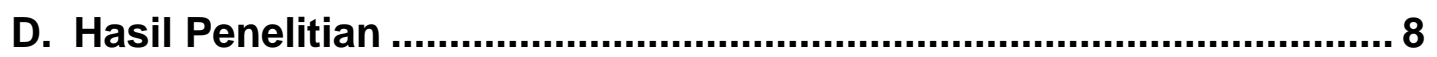

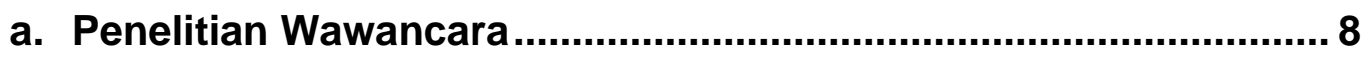

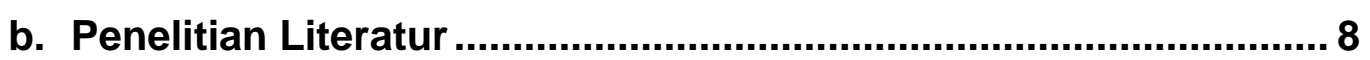

BAB IV TINJAUAN ETIKA KRISTEN........................................................ 10

A. Pandangan Alkitab Tentang Napza .............................................. 10

B. Alkitab Memberi Peringatan.......................................................... 11

C. Hanya Allah Yang Mampu Memulihkan .......................................... 11

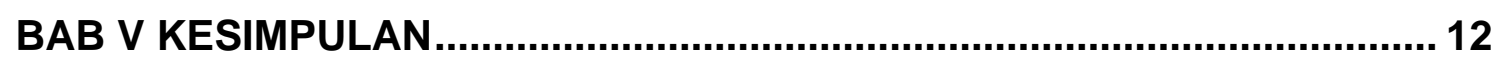

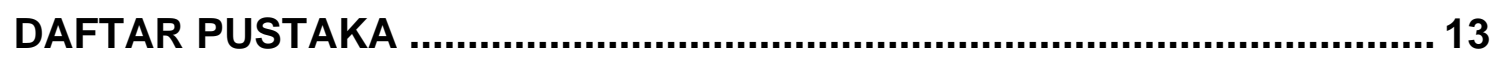




\section{BAB I \\ PENDAHULUAN}

Di era postmodern ini, sangat banyak anak muda, orang dewasa bahkan anak remaja hingga anak di bawah umur yang marak mengkonsumsi narkoba, psikotropika dan zat adiktif lainnya atau disebut napza.

\section{A. Latar Belakang Masalah}

Napza singkatan dari narkotika, psikotropika dan zat adiktif yang sesungguhnya mengandung bahan-bahan berbahaya, namun diciptakan untuk kebutuhan medis dan pengobatan serta memiliki efek tersendiri, oleh karena itu peredarannya sangat diatur oleh pemerintah. Diatur oleh pemerintah berdasarkan keputusan Menteri Kesehatan RI No.1999/MenKes/SK/X/1996, Pedangan Besar Farmasi (PBF) Kimia Farma mengemukakan bahwa kepentingan pengobatan dan ilmu pengetahuan dipertanggungjawabkan oleh Pengawasan Obat dan Makanan (POM) yang bertujuan untuk memudahkan pengawasan narkotika oleh pemerintah. ${ }^{1}$

Pada tindakan operasi, kokain (narkotika golongan I) sangat bermanfaat digunakan untuk obat bius atau penahan rasa sakit, sedangkan kodein (narkotika golongan III) yang merupakan analgesik lemah yang kekuatannya sekitar 1/12 dari morfin. Karena itu kodein tidak termasuk dalam analgesik, tetapi sebagai anti kuat. Analgesik sendiri merupakan obat yang dapat menghilangkan rasa nyeri pada penderita dan akhirnya memberikan rasa nyaman pada penderita tersebut. ${ }^{2}$ Morfin sendiri juga digunakan untuk penghilang rasa sakit dalam proses operasi. Psikotropika kebanyakan digunakan untuk mengatasi masalah kejiwaan seseorang, amfetamin untuk mengatasi masalah kegemukan dan depresi bahkan juga digunakan sebagai obat penenang sebelum operasi, Nitrazepam dan Diazepam untuk mengatasi masalah insomnia dan kecemasan berlebih, phenobarbital sebagai obat tidur. ${ }^{3}$ Zat adiktif seperti nikotin dalam bidang kedokteran yaitu pada dosis tertentu, nikotin yang terdapat pada rokok dapat memulihkan ingatan seseorang. Hal ini terjadi karen nikotin

\footnotetext{
${ }^{1}$ https://www.kompasiana.com/fatwaalfia/54f92f71a3331178178b46d6/manfaat-obat-yangmengandung-narkotika

2 https://media.neliti.com/media/publications/170823-ID-kegunaan-narkotika-dalam-duniamedis.pdf

${ }^{3} \mathrm{http}: / /$ ujiansma.com/manfaat-narkoba-dalam-dunia-kesehatan
} 
dapat merangsang sensor penerima rangsangan di otak, serta alkohol yang dapat membunuh kuman penyakit, sehingga biasa digunakan untuk membersihkan alat-alat kedokteran pada proses sterilisasi. ${ }^{4}$

Melalui pemaparan di atas sesungguhnya napza sangat bermanfaat di dunia kedokteran dalam upaya pemulihan kesehatan manusia, namun banyak kandungan yang berbahaya di dalamnya sehingga peredaran sangat ketat diatur oleh pemerintah, akan tetapi faktanya kandungan-kandungan dalam napza dijadikan berbagai obatobatan yang dijual secara illegal di dunia seperti: heroin, kokain, ekstasi, ganja, sabusabu dan lain-lain. Hal ini merusak populasi manusia dari berbagai kalangan sehingga mereka disebut sebagai korban napza.

Dengan demikian penelitian ini dilakukan oleh peneliti guna mencari solusi dengan memaparkan beberapa hal tentang napza dan korban napza hingga pada penelitian yang dilakukan untuk mendapatkan factor penyebab dan dampak serta tinjauan etika Kristen dalam menghadapi para korban napza tersebut.

\section{B. Rumusan Masalah}

1. Apa itu Napza?

2. Apa faktor penyebab dan dampaknya?

3. Bagaimana tinjauan etika Kristen terhadap korban napza?

\section{Tujuan Penelitian}

1. Untuk mengetahui arti napza.

2. Untuk mengetahui faktor penyebab dan dampaknya.

3. Untuk mengetahui tinjauan etika Kristen terhadap korban napza. 


\section{BAB II \\ NAPZA}

\section{A. Pengertian Napza}

NAPZA adalah singkatan dari Narkotika, Psikotropika, dan Zat Adiktif lainnya. Pengertian NAPZA secara umum adalah semua zat kimiawi yang jika dimasukkan ke dalam tubuh manusia, baik secara oral (diminum, dihisap, dihirup dan disedot) maupun disuntik, dapat mempengaruhi kejiwaan/ psikologis dan kesehatan seseorang, serta menimbulkan kecanduan atau ketergantungan. ${ }^{5}$

\section{B. Macam-macam Napza ${ }^{6}$}

Setelah memahami definisi NAPZA, selanjutnya kita juga perlu tahu apa saja jenis-jenis NAPZA yang ada di masyarkat. Sesuai UU No. 22 Tahun 1997, NAPZA dapat dibedakan menjadi beberapa jenis, diantaranya adalah:

\section{Narkotika}

Dari pengertian NAPZA di atas, narkotika adalah salah satu yang termasuk golongan NAPZA dimana terbuat dari suatu tanaman maupun non-tanaman baik yang sintetis maupun yang semi sintetis dan bisa menyebabkan perubahan dan penurunan kesadaran.

\section{Psikotropika}

Jenis kedua dari NAPZA yaitu psikotropika yang merupakan bahan alami maupun bukan alami yang memiliki khasiat psikoaktif. Dampak mengkonsumsi psikotropika dapat mempengaruhi susunan saraf yang bisa menyebabkan perubahan mental dan perilaku.

\section{Zat Adiktif}

Zat adiktif tidak termasuk narkotika maupun psikotropika, dimana zat ini merupakan bentuk inhalasi dan penggunaanya dapat menimbulkan ketergantungan. Zat adiktif ini mudah kita temukan di kehidupan sehari-hari, misalnya

\footnotetext{
${ }^{5}$ https://www.maxmanroe.com/vid/umum/pengertian-napza.html

6 lbid
} 
Nikotin pada rokok, Etanol pada minuman beralkohol, dan pelarut yang mudah menguap pada thiner, lem, dan lain-lain.

\section{Contoh jenis-jenis Napza}

Adapun yang menjadi jenis-jenis Napza adalah: ${ }^{7}$

1. Narkotika : Morfin, Kokain, Heroin, Opium, Ganja.

2. Psikotropika : Ekstasi, Sabu-sabu, Amphetamin.

3. Zat Adiktif : Alkohol atau Etanol, Nikotin, Kafein.

\section{BAB III METODE PENELITIAN, FAKTOR PENYEBAB DAN DAMPAK}

\section{A. Metode Penelitian}

Peneliti menggunakan metode deskriptif dengan pendekatan kualitatif. Metode deskriptif adalah metode penelitian dengan mengumpulkan data, memberikan gambaran, penegasan suatu konteks atau gejala serta menjawab pertanyaan sehubungan dengan status subjek penelitian ini. ${ }^{8}$ Lebih komprehensif dan mendetail, Nazir mendefinisikan tentang metode deskriptif, yang adalah:

Suatu metode dalam meneliti status kelompok manusia, suatu objek, suatu set kondisi, suatu sistem pemikiran atau kelas peristiwa yang terjadi pada masa sekarang. Penelitian ini bertujuan untuk memberikan gambaran secara sistematis, faktual dan akurat mengenai fakta-fakta, sifat-sifat, serta lambang antara fenomena yang diselidiki. ${ }^{9}$

Maka peneliti menggunakan metode deskriptif, karena peneliti berupaya untuk memberikan suatu gambaran akan fakta dari suatu fenomena yang terjadi bagi korban napza.

7 https://www.liputan6.com/health/read/3766152/jenis-jenis-narkoba-dan-bahayanya-bagitubuh-efeknya-mengerikan

${ }^{8}$ Sumanto, Metode Penelitian Sosial dan Pendidikan, (Yogyakarta: ANDI Offset,1990), 109

9Mohamad Nazir, Metode Penelitian, (Jakarta : Ghalia Indonesia, 1985), 63 
Pendekatan kualitatif adalah suatu proses penelitian yang menekankan pada proses dan makna yang tidak secara ketat diperiksa atau diukur dari segi jumlah, intensitas dan frekuensinya, tetapi menekankan sifat realitas yang disusun secara sosial, hubungan antara peneliti dan yang diteliti, dan pembatasan situasional yang membentuk penelitian. ${ }^{10}$ Pendekatan kualitatif lebih menekankan makna, penalaran, definisi suatu situasi tertentu (dalam konteks tertentu) dan lebih banyak meneliti halhal yang berhubungan dengan suatu fenomena sosial dan masalah manusia dalam kehidupan sehari-hari atau bersifat natural. ${ }^{11}$

Peneliti menggunakan pendekatan kualitatif dikarenakan selain peneliti menyelidiki, meneliti literature, peneliti juga mewawancarai langsung korban napza.

\section{B. Data Wawancara}

Peneliti melakukan wawancara terhadap dua orang korban Napza, pertama seorang pemuda berinisial DM adalah pecandu narkotika berat yang sedang melakukan proses rehabilitasi di suatu tempat rehabilitasi dan yang kedua berinisial SV adalah seorang pecandu psikotropika ringan yang tidak menjalani rehabilitasi sebab belum sangat ketergantungan, namun keduanya adalah konsumen aktif dari zat adiktif rokok dan alkohol.

\section{Narasumber 1 Kode: CPL-1}

Nama : DM

Usia : 25 tahun

Waktu : 20 November 2019, pkl 18.15 wib

Tempat : Kebon Jeruk, Jakarta Barat (wawancara via telp)

Pertanyaan 1: Apa faktor penyebab anda menggunakan Napza?

Jawaban :

- Saya mengalami depresi karena ibu yang terlalu keras dalam mendidik, ayah yang cuek dan kakak yang sangat galak sehingga membuat saya divonis

${ }^{10}$ Andreas B. Subagyo, Pengantar Riset Kuantitatif dan Kualitatif, (Bandung: Yayasan Kalam Hidup, 2004), 62

${ }^{11}$ Iskandar, Metodologi Penelitian Kualitatif, (Jakarta: Gaung Persada, 2009), 11 
menderita penyakit jiwa bipolar (gangguan dua kepribadian) dan skizofrenia oleh seorang psikolog.

- Karena sering mendengar suara-suara yang aneh dan membuatnya cemas dan tidak nyaman serta depresi akhirnya saya menggunakan Napza untuk menenangkan diri.

- Saya bergaul dengan komunitas pengguna napza yang membuat saya mencoba dan ketahgihan

Pertanyaan 2: Apa dampak dari penggunaan Napza?

Jawaban :

- Membuat saya ketagihan, sehingga ingin terus menerus menggunakan.

- Semua uang hasil saya bekerja habis hanya untuk membeli narkoba.

- Saya kehilangan pekerjaan.

- Saya dibenci ayah dan kakak saya.

- Gangguan kejiwaan saya semakin berat.

2. Narasumber 1

\section{Kode: CPL-1}

Nama :SV

Usia : 32 tahun

Waktu : 21 November 2019, pkl 19.00 wib

Tempat : Kebon Jeruk, Jakarta Barat (wawancara via telp)

Pertanyaan 1: Apa faktor penyebab anda menggunakan Napza?

Jawaban :

- Saya mengalami depresi karena ayah saya memaksakan saya untuk menjadi dokter, dan saya gagal mengikuti ujian tes untuk menjadi dokter, walau saya adalah sarjana kesehatan.

- Akhirnya saya hanya bekerja di bagian farmasi dan mudah mendapat akses untuk memiliki napza, dan mulai mencobanya.

- Kemudian saya bergaul dengan para pengedar dan mulai mengkonsumsi secara ringan sambal mengedarkan. Tetapi sudah saya stop karena teman saya masuk penjara. Sekarang saya hanya menggunakan psikotropika ringan 
saja untuk menghilangkan rasa depresi atas tuntutan keluarga, seperti diazepam dan sedikit amfetamin, serta ekstasi untuk sosialisasi dalam pergaulan.

Pertanyaan 2: Apa dampak dari penggunaan Napza?

Jawaban :

- Membuat saya dibenci oleh ayah saya sehingga hubungan kami buruk.

- Keluarga saya selalu mencurigai saya dan tidak memberikan kenyamanan bagi saya.

- Saya kehilangan pekerjaan.

- Hubungan saya dengan anak dan istri tidak baik.

- Depresi semakin mendalam dan masalah baru terus menerus muncul.

\section{Hasil Wawancara}

Dari hasil penelitian yang peneliti lakukan, maka peneliti menemukan adanya faktor penyebab dan dampak yang dialami oleh kedua korban napza tersebut.

Pertama seorang yang berinisial DM, ia ternyata mengalami depresi dan tekanan yang luar biasa sejak kecil dari keluarganya yang menyebabkan ia divonis bipolar dan skizofrenia ringan oleh seorang psikolog, sehingga ia harus mengkonsumsi napza yang awalnya dosis ringan menjadi ketagihan dan penyalahgunaan yang berlebihan, ditambah pergaulan yang membuat ia mudah mendapatkan dosis yang melebihi yang ia butuhkan, sehingga dampaknya ia menjadi pecandu berat dan harus menjalani rehabilitasi kecanduan napza dan kejiwaan, pekerjaan hilang serta hubungan dengan keluarga berantakan.

Kedua seorang berinisial SV, karena tuntutan ayahnya untuk dirinya menjadi dokter dan gagal akhirnya iapun depresi dan sebagai seorang sarjana kesehatan, dengan akses ke dunia farmasi membuatnya mencoba menggunakan psikotropika ringan untuk menenangkan diri, tetapi karena adanya pergaulan yang lebih mendalam iapun sempat menjadi pengedar narkoba, namun nasib baik ada padanya sebab temannya seorang pengedar harus ditangkap dan iapun luput, akhirnya ia berhenti sebentar namun sesekali ia menggunakan hanya untuk ketenangan dan sosialisasi dalam pergaulan. Semua yang ia lakukan berdampak buruk bagi kejiwaannya sebab 
depresi tidak hilang hanya menimbulkan masalah baru dan hubungannya dengan ayahnya, istri dan anaknya menjadi tidak baik bahkan ia harus kehilangan pekerjaan dan masa depannya hancur berantakan.

\section{Hasil Penelitian}

Pada bagian ini, penulis akan menjelaskan hasil penelitian yang telah dilakukan yaitu:

\section{a. Penelitian Lapangan}

Melalui data wawancara yang peneliti dapatkan, maka peneliti akan memaparkan hasil wawancara berikut:

Yang menjadi faktor penyebab penggunaan napza adalah:

1. Hubungan keluarga yang kurang harmonis dan menghasilkan depresi atau kekecewaan.

2. Adanya gangguan kejiwaan dan butuh napza untuk menenangkan diri.

3. Sekedar coba-coba dan memiliki akses untuk mendapatkan napza

4. Bergaul dengan para pengguna dan pecandu napza.

Sedangkan yang menjadi dampaknya adalah:

1. Ketergantugan.

2. Merusak tubuh dan kejiwaan seseorang.

3. Merusak hubungan dengan keluarga.

4. Kehilangan pekerjaan serta menghancurkan masa depan dan cita-cita.

\section{b. Penelitian literatur}

Peneliti juga mencari data literatur melalui tulisan-tulisan yang dipaparkan dalam internet mengenai faktor penyebab penggunaan napza yaitu: ${ }^{12}$

\section{Faktor pribadi}

- Mental yang lemah: mudah terpengaruh hal yang buruk.

- Stres dan depresi: masalah yang berat membuat salah ambil keputusan. 
- Ingin tahu dan coba-coba: rasa penasaran yang membuat ketagihan.

- Mencari sensasi dan tantangan: agar dianggap hebat oleh teman-temannya.

\section{Faktor keluarga}

- Broken home: anak selalu menjadi korban dari keluarga yang pisah sehingga salah arah.

- Kurangnya perhatian orang tua terhadap anak: orang tua terlalu sibuk bekerja hingga lupa menanamkan pendidikan moral dalam keluarga.

- Terlalu memanjakan anak: anak menjadi seenaknya terhadap orang tua.

- Terlalu keras pada anak: saat anak beranjak dewasa menjadi memberontak sebab sikap otoriter orang tua mengganggu mental anak.

- Kurangnya komunikasi dan keterbukaan: situasi kaku dalam keluarga membuat anak tertutup dan memendam masalah mereka.

\section{Faktor sosial}

- Salah bergaul: anak terjerumus dalam pergaulan yang kelewat batas.

- Ikut-ikutan: agar dianggap setiakawan dalam pergaulan tersebut sehingga anak terjerumus.

\section{Faktor ekonomi}

- Karena hidup dalam keluarga miskin yang membuat anak menjadi pengedar dan pemakai narkoba.

Sedangkan yang akhirnya menjadi dampak dalam penggunaan napza dalam kehidupan adalah: ${ }^{13}$

\section{Dampak Fisik:}

- Gangguan pada system syaraf (neurologis) seperti: kejang-kejang, halusinasi, gangguan kesadaran, kerusakan syaraf tepi.

${ }^{13} \mathrm{https}: / / c o m m u n i c a t i o n . b i n u s . a c . i d / 2019 / 01 / 22 /$ dampak-penggunaan-narkoba-bagi-generasimuda-2/ 
- Gangguan pada jantung dan pembuluh darah (kardiovaskuler) seperti: infeksi akut otot jantung, gangguan peredaran darah.

- Gangguan pada kulit (dermatologis) seperti: penanahan (abses), alergi, eksim.

- Gangguan pada paru-paru (pulmoner) seperti.

- Dampak terhadap kesehatan reproduksi adalah gangguan padaendokrin, seperti: penurunan fungsi hormon reproduksi (estrogen, progesteron, testosteron), serta gangguan fungsi seksual.

- Dampak terhadap kesehatan reproduksi pada remaja perempuan antara lain perubahan periode menstruasi, ketidakteraturan menstruasi, dan amenorhoe (tidak haid).

- Bagi pengguna narkoba melalui jarum suntik, khususnya pemakaian jarum suntik secara bergantian, risikonya adalah tertular penyakit seperti hepatitis $B, C$, dan HIV yang hingga saat ini belum ada obatnya.

- Penyalahgunaan narkoba bisa berakibat fatal ketika terjadi Over Dosis yang dapat menyebabkan kematian.

\section{Dampak Psikis dan Sosial bagi pemakai narkoba antara lain :}

- Lamban kerja, ceroboh kerja, sering tegang dan gelisah.

- Hilang kepercayaan diri, apatis, pengkhayal, penuh curiga.

- Agitatif, menjadi ganas dan tingkah laku yang brutal.

- Sulit berkonsentrasi, perasaan kesal dan tertekan.

- Cenderung menyakiti diri, perasaan tidak aman, bahkan bunuh diri.

- Gangguan mental, anti-sosial dan asusila, dikucilkan oleh lingkungan.

- Merepotkan dan menjadi beban keluarga.

- Pendidikan menjadi terganggu, masa depan suram.

\section{BAB IV}

TINJAUAN ETIKA KRISTEN TERHADAP KORBAN NAPZA

\section{A. Pandangan Alkitab tentang napza.}


Alkitab menjelaskan di dalam Gal. 5:20-21 tentang perbuatan daging yang merupakan tabiat berdosa, dimana terdapat kata sihir (yun: pharmakeia) yaitu: ilmu sihir, spiritisme, menyembah setan dan penggunaan obat bius untuk memperoleh pengalaman-pengalaman rohani (Kel. 7:11, 22; 8:18; Why. 9:21, 18:23). ${ }^{14}$ Artinya penggunaan obat bius seringkali dilakukan untuk merasakan spiritualitas yang keliru dan ini merupakan kekejian bagi Tuhan sebab orang yang tersihir atau sugesti oleh Napza akan selalu melakukan hal yang tidak baik dan benar, sehingga sekali orang mencoba narkotika dan psikotropika maka ia bisa dikatakan telah terikat dengan praktek okultisme atau kuasa gelap, sehingga sulit untuk dilepaskan. Selain itu kata pesta pora (yun: komos), yaitu berpesta dan bersukaria secara berlebihan, suasana pesta pora yang identik dengan minuman keras, obat bius (Napza), acara seks dan semacamnya. ${ }^{15}$ Hal ini juga merupakan kekejian di hadapan Tuhan, maka penggunaan narkotika baik untuk hal-hal spiritual maupun kesenangan itu merupakan tabiat berdosa, dan akan mengikat jiwa seseorang.

Zat adiktif juga mampu membuat orang tidak mampu mengendalikan diri mereka dan selalu bersikap tidak benar karena kehilangan akal serta bertentangan dengan ajaran Alkitab (Mzm. 107:27), oleh karena itu Firman Tuhan senantiasa menjelaskan dan mengajar agar manusia mampu menguasai diri agar tidak mabuk yang berlebihan dan menimbulkan hawa nafsu daging (Ef. 5:18). Bahkan jelas dalam Alkitab juga dikatakan bahwa pemabuk tidak dapat tempat dalam Kerajaan Allah (1 Kor. 6:10).

\section{B. Alkitab memberikan peringatan terhadap bahaya penggunaan Napza.}

Seringkali mereka yang menggunakan napza, adalah akibat dari salah bergaul dalam suatu komunitas yang tidak baik, maka Alkitab menjelaskan bahwa pentingnya seseorang untuk waspada dalam memilih komunitas ia berada agar tidak terjebak, sebab pergaulan yang buruk merusak kebiasaan yang baik (1 Kor. 15:33).

Dalam Gal. 5:21, kata kemabukan (yun: methe) akan menghasilkan kerusakan penguasaan mental atau fisik dengan minuman keras. ${ }^{16}$ Maka sebagai orang percaya

${ }^{14}$ Donald C. Stamps, Alkitab Penuntun Hidup Berkelimpahan, (Malang: Gandum Mas dan LAl, 1994), 1954

$15 \mathrm{lbid}$

${ }^{16}$ Donald C. Stamps, Alkitab Penuntun Hidup Berkelimpahan,. 1954 
tidak seharusnya hidup dikuasai oleh minuman keras yang memabukan dan merusak tubuh.

Tubuh orang percaya adalah tempat kediaman Roh Allah atau disebut juga Bait Allah, maka harus dijaga dan dipelihara dengan seksama jangan sampai ada pencemaran dalam bentuk apapun (1 Kor. 3:16).

Alkitab juga mengajar bahwa orang percaya harus "meninggalkan kefasikan dan keinginan-keinginan duniawi dan supaya kita hidup bijaksana, adil dan beribadah di dalam dunia sekarang ini" (Titus 2:12). ${ }^{17}$

\section{Hanya Allah Yang Mampu Memulihkan.}

Di dalam Alkitab, ide tentang keselamatan selalu dihubungkan dengan tindakan Allah Bapa di dalam Tuhan Yesus Kristus untuk menyembuhkan dan memulihkan umat manusia (Mrk 5:34), membebaskan dari dosa dan pengaruhnya (Tit. 3:6-7) dan mengampuni dosa (Luk. 7:47-48)..$^{18}$ Oleh karena itu hanya kuasa Tuhan saja yang mampu melepaskan orang dari keterikatan Napza, sehingga para korban napza harus dilayani bukan hanya jasmani atau fisiknya saja tetapi yang paling hakiki yaitu kerohaniannya, dengan spiritual terapi yang membawa mereka kepada kasih Tuhan yang kekal dan menerima Kristus sebagai juruselamat secara pribadi. Dengan demikian pemulihan secara total akan menjadi bagian bagi para korban napza tersebut.

\section{BAB V KESIMPULAN}

Napza seharusnya mengandung bahan-bahan yang sangat bermanfaat namun karena tindakan buruk manusia, maka terjadi penyalahgunaan napza tersebut yang akhirnya menciptakan korban napza, dimana korban napza menjadi suatu masalah berat yang sulit diatasi. Hasil penelitian yang dilakukan menjelaskan bahwa penyalahgunaan dan keburukan sikap manusia menjadi latar belakang masalah yang terjadi dalam seputar kegiatan napza, maka terciptalah pecandu napza yang juga disebut sebagai korban napza. Faktor yang menyebabkan mereka menjadi pengguna

\footnotetext{
17 https://www.gotquestions.org//ndonesia/narkoba.html

18 Yakub Susabda, Pastoral Konseling Jilid I, (Malang: Gandum Mas, 2012), 78
} 
secara khusus adalah karena pondasi jiwa yang rapuh sehingga berdampak buruk pada raga dan status hidup bahkan masa depan. Oleh karena itu sesungguhnya korban napza dapat diatasi apabila adanya sikap etis Kristen yang berlandaskan Alkitab saja bagi orang percaya untuk mau mengulurkan tangan dan membantu para korban napza agar mereka dapat pulih

Dengan demikian, sebagai orang percaya sebaiknya mau turun tangan untuk menolong para korban napza dan tidak menilai buruk hidup mereka, menghakimi bahkan menganggap mereka sebagai sampah atau racun masyarakat, tetapi dengan kasih melayani, karena mereka adalah korban yang terjebak dalam situasi yang belum tentu mereka inginkan.

\section{Daftar Pustaka}

\section{A. Buku}

1. Iskandar.,

2009 Metodologi Penelitian Kualitatif, Jakarta: Gaung Persada.

2. Nazir, Mohamad., 
1985 Metode Penelitian, Jakarta : Ghalia Indonesia.

3. Stamps, Donald C., 1994 Alkitab Penuntun Hidup Berkelimpahan, Malang: Gandum Mas.

4. Subagyo, Andreas B., 2004 Pengantar Riset Kuantitatif dan Kualitatif, Bandung: YKH.

5. Sumanto.,

1990 Metode Penelitian Sosial dan Pendidikan, Yogyakarta: ANDI Offset.

6. Susabda, Yakub.,

2012 Pastoral Konseling Jilid I, Malang: Gandum Mas.

\section{B. Internet}

1. http://ujiansma.com/manfaat-narkoba-dalam-dunia-kesehatan

2. https://communication.binus.ac.id/2019/01/22/dampak-penggunaan-narkobabagi-generasi-muda-2/

3. https://media.neliti.com/media/publications/170823-ID-kegunaan-narkotikadalam-dunia-medis.pdf

4. https://www.gotquestions.org/Indonesia/narkoba.html

5. https://www.kompasiana.com/fatwaalfia/54f92f71a3331178178b46d6/manfaatobat-yang-mengandung-narkotika

6. https://www.kompasiana.com/fatwaalfia/54f92f71a3331178178b46d6/manfaatobat-yang-mengandung-narkotika

7. https://www.liputan6.com/health/read/3766152/jenis-jenis-narkoba-danbahayanya-bagi-tubuh-efeknya-mengerikan

8. https://www.maxmanroe.com/vid/umum/pengertian-napza.html

9. https://www.pelangiblog.com/2016/01/5-faktor-utama-penyebabpenyalahgunaan.html 